\title{
Parity in Political Institutions in the DR.Congo for the Emergence of the Good Governance: Low Representation of Women in the National Executive Institutions
}

\author{
Chelo Kpats Guyguy \\ College of Sociology, Central China Normal University, Wuhan, China \\ Email: guyguy.chelokpats@yahoo.com
}

How to cite this paper: Guyguy, C. K. (2020). Parity in Political Institutions in the DR.Congo for the Emergence of the Good Governance: Low Representation of Women in the National Executive Institutions. Open Journal of Social Sciences, 8, 210-231. https://doi.org/10.4236/jss.2020.85015

Received: April 7, 2020

Accepted: May 16, 2020

Published: May 19, 2020

Copyright $\odot 2020$ by author(s) and Scientific Research Publishing Inc. This work is licensed under the Creative Commons Attribution International License (CC BY 4.0).

http://creativecommons.org/licenses/by/4.0/

\begin{abstract}
The political field is a space where women are represented through the process of legitimizing naturalistic ideology. It provides a room for women to present their issues about political, social and economic development for the benefits of the nation and the world. Gender participation in politics is a special aspect, and no women should be left behind regardless of her difference of race, gender and religion. In the political institutions, parity is socially constructed as masculine in many societies. Gender parity is an issue which has been discussed worldwide within International and National Organizations on how to promote equal opportunity between men and women for good governance. Women have been facing many challenges in participating in political institutions. However, the political obstacles are not the least the resignation of a woman from her responsibilities as wife and mother. Women should be given equal chance with men to participate in political institutions for individual and nation development. The battle for gender-parity, which resulted in the enactment of the Parity Act in October 2015 in Congo aimed to promote gender equity and equal rights, opportunities throughout national life. This may include the equitable participation of women and men in the management of State affairs. Unfortunately, this Act did not meet the expectations of its application. In this paper, the discussion also includes the concept of gender and the beginning of gender awareness among the group of elite women in the USA that is known as Feminism. The paper also discusses the significance of conducting field research to prove the low representation of women in the Congolese national executive, Legal and policy framework for the advancement of women in the DR.Congo: status of gender parity in the institutions of the DR.Congo from February 2006 to March 2018. It is clear
\end{abstract}


that policy of recognition should be created and strengthened to promote social status, i.e. the status of women as full partners in the political interaction. Furthermore, the paper points out factors contributing to low representation of women in political institutions. The paper further provides an argument on the importance of gender parity in political institutions in the nation.

\section{Keywords}

Gender-Parity, Political Institutions, Emergence and Good Governance

\section{Introduction}

The notion of gender is examined here through some of its possible uses in the history of feminism. Produced by feminist women, it helps to unveil the unequal redistribution of power between sexes. It could also illuminate some aspects of feminism's internal history. It is especially crucial when one is interested in the awareness of the subjects. Studies are the result of recent, but already well-established feminist studies. They were institutionalized in the United States in the year 1980. However, at the same time, feminist studies are struggling to impose themselves in France because they are stigmatized as "militant sciences". Relevant research on women exists, but not as an autonomous field. Indeed, many feminist researchers use the concept of "gender" with distrust, because it is considered an American creation. Nevertheless, it has been largely imposed since the year $2000 .^{1}$

Indeed, we recognize with Dr. Christina Scharff. Having interviewed a diverse group of young women German and British women for his research, he found associations of the term "feminism" with man-hating; lesbianism or lack of femininity was a key factor in the rejection of the label "feminist". The majority said that they did not want to be calling themselves feminist because they feared that they would be associated with these traits. It's in despite of many stressing they were not homophobic and some identifying as lesbian or bisexual. ${ }^{2}$

Parini, L. (2006: p. 10) said that: "Any study that helps to highlight the role, contributions and more generally the experience of women contains a feminist potential, as it contributes to the visibility of a social group largely forgotten by research (...). In addition to highlighting women inevitably leads to wonder about the reasons for their occultation and thus to have a feminist look at these phenomena". We use this pretext to reflect on the low representation of women in the Congolese national executive and legislative.

At the outset, Congolese women need to be aware of the situation in order to get out of this straitjacket of marginalization. However, democracy requires women to struggle to be heard in order to position themselves and to be at the ${ }^{\text {https://cafaitgenre.org/2014/02/25/genre-et-feminisme-pourquoi-vont-ils-de-pair/. }}$

${ }^{2} \mathrm{Dr}$ Christina Scharff, Why so many young women don't call themselves feminist, King's College London, https://www.bbc.com/news/uk-politics-Accessed on February 12. 
level of all political bodies' decision-making, notably by strengthening their leadership in politics to better position themselves in the leadership of political parties and elective positions. Alas, a kind of lack of leadership of women in politics is illustrated by their low representation in political institutions as well as political party leaders in the DR.Congo.

\section{Literature Review}

Discrimination against women has been institutionalized through state norms and practices. These are based on their foundations, as well affirms Commaille, J. (1997: p. 10), "In the logic or values structuring a society". Moreover, it is in the field of politics that this discrimination is mostly felt. This is all the more true as says Kergoat, D. (2007: p. 36), "the sexual division of Labour has as its characteristics the priority assignment of men to the productive sphere and of women to the reproductive sphere, and simultaneously the capture by men of functions with high added value (political, Military, religious, etc.)."

It should be recalled that since the proclamation of the Year of Women (1975) and the United Nations Decade for Women (1976-1985), the Democratic Republic of the Congo has taken part in all the world conferences on women. It endorsed the various United Nations Recommendations for the advancement of women, including those contained in the Beijing Platform in September 1995. Among all these recommendations, we hold in the context of this reflection, promotion to the positions of decision-making (RDC, 2007).

In short, as a sociologist, we believe that the question of gender is due to cultural gravity because it embodies a sociological question. It has passed on to the level of community where there is a kind of perpetuation of discrimination based on sex. With the example of a citizen who has experienced sex discrimination in his family or with his own sister, think you he'll understand that it is necessary to give importance to the matter related to gender? As so, we are faced with a sociological reality that requires a time for change.

At the national level, the Democratic Republic of the Congo has ratified all instruments relating to the advancement of women in all areas of national life. Articles 14 and 15 of the Constitution of 18 February 2006, to name but a few, clearly stipulate that women must participate fairly in the political institutions of the Republic. Just recently, the parity battle found an outcome through the Parity law promulgated in October 2015. This law comes to clarify the measures of application of the constitutional provisions evoked. From now on before, the DR.Congo 2006 Constitution of the Republic stipulates that "the state shall ensure the elimination of all forms of discrimination against women and ensure the protection and promotion of their rights in all fields, including civil, political, economic, social and cultural fields. The state will take all appropriate measures to ensure the full development and full participation of women in national development. It will also take action against any form of violence against women in public life and in private life. Women have the right to fair representation in 
national, provincial and local institutions. The state shall ensure the implementation of gender equality in these institutions" (Article 14). ${ }^{3}$

In addition, in articles 12 and 14 of the Constitution, the principles of equal rights, good luck and sex, the Democratic Republic of the Congo has ratified several international, regional and sub-regional legal instruments relating to human rights, in particular ${ }^{4}$ :

$\checkmark$ The Universal Declaration of Human Rights;

$\checkmark$ The Protocol to the African Charter on Human and Peoples' Rights on the Rights of Women;

$\checkmark$ The United Nations Convention on the Rights of the Child;

$\checkmark$ The Convention on the Elimination of All Discrimination Against Women;

$\checkmark$ SADC Memorandum of Understanding on Gender and Development;

$\checkmark$ United Nations Resolution 1325 .

These international, regional and sub-regional legal instruments proclaim equality of rights between men and women and constitute as many commitments for the Democratic Republic of the Congo to take legal and administrative measures for the enjoyment of these rights by women. Thus, the purpose of this Law is to promote gender equity and equal rights, opportunities for both sexes throughout national life, including the equitable participation of women and men in the management state affairs.

In this respect, Le Doaré, H. (2007: p. 143) notes that gender inequality in representation would undermine the foundations of representation of democracy. Parity, which in its numerical form, is thought to be a specific modality for equality, should help to rethink a manifestly deficient democratic system since it was unable to integrate half of the citizens. In the same register (Schwartzenberg, 1998: p. 198). Pye LW says that a political system is said to be developed when it ensures a certain gender equality trend. And yet, in fact, the application of this principle is thrust to several obstacles. There is, therefore, a break between the state rule and the practice which deserves to be taken over in the analyses.

However, recent surveys show that challenges and opportunities of women political participation remains an interesting issue. Kassa, S. (2015) pointed out that the under representation of women political participation in decision making positions is a challenge. Using a qualitative method and secondary sources, the author identified the causal factors that contribute to that problem of under representation of women in politics. These factors include economic, religious, social and cultural. The conclusion was that women participation in politics and decision making allow women to address their problems.

Another issue is advancing equality in the representation of women in local politics. In Israel, for instance, an increase in women participation was observed due to organized, systematic and focused actions made to explain factors that led to that increase. Akirav, O and Ben-Horin, Y. (2016) applied "The Four Anchors ${ }^{3}$ http://extwprlegs1.fao.org/docs/pdf/cng154963.pdf.

${ }^{4}$ https://www.idea.int/sites/default/files/publications/political-parties-in-africa-through-a-gender-len s.pdf. 
Model" in which they list authentic leadership, organization with gender awareness, practice that provide organized training and networking for women. The results of training show that women displayed authentic leadership and training that enable them to participation in political positions.

Political participation in the local government drew the attention of the researchers in the third world as well. Rameez, A. (2018) focuses on the level of women participation in the local government in Sri Lanka. The study explored the reasons behind low participation of women in politics. Although women are the majority, only $5 \%$ actively participated in political positions. Their participation was ascribed to financial support made available for collective organized groups. However, women participation is confined to voting, while other activities are left to men. Women are also able to secure support from various sources such family, friends, neighbors and civil societies. The level of participation of women remains low because of a number of factors. There are biological, economic, psychological, religious and political factors that hinder their participation in politics. Women in Sri Lanka are negatively influenced by the apprehension, inferiority complex, poverty, lack of financial strength, social norms and discouragement from religious leaders.

This leads to question the low representation of women in the national Executive in the Democratic Republic of the Congo from February 2006 to March 2018 , and this is the concern that we will try to answer throughout this study. To do this, we refer our questioning to gender as a category of analysis. This forces us to think in relational and systemic terms all the social phenomena that affect the relationship between women and men (Parini, 2006: p. 15). Because "the characteristics associated with each sex are socially constructed in an opposition relationship. Therefore, it is not possible to study what belongs to women and the feminine without articulating the analysis with men and the masculine" (Bereni et al., 2008: p. 5).

With the help of our questioning on the gender, enlightened by the low representation of women within the national executive, the article analyzes the awareness of Congolese women in order to break out of this shackles of marginalization. Thus, to properly understand this article, we have resorted to the systematic approach in analyzing and criticizing the social facts that affect Congolese women in the Democratic Republic of the Congo. Thus, apart from the introduction and conclusion, our remarks will revolve around the following three points:

$\checkmark$ Legal and policy framework for the advancement of women in the DR.Congo;

$\checkmark$ Status of gender parity in the institutions of the DR.Congo from February 2006 to March 2018;

$\checkmark$ Low representation of women in the National Executive.

This introductory point brings us into the work. We can move straight to the discussion in order to allow us to present the legal and policy framework for the advancement of women participation in politics and public life in the DR. Con- 
go as well as the intellectual exercise which is the basic subject of this article.

\section{Discussion}

\subsection{Legal and Policy Framework for the Advancement of Women in the DR.Congo}

Before analyzing the low presence of women in the national executive and legislative, it is necessary to give an overview of the legal and political framework for the advancement of woman. This is based on the international and national instruments that:

\section{1) On the International level}

\section{$\checkmark$ Beijing Platform}

The Beijing Platform for Action notes the need to recognize the similarities and differences between women and men and to give them the same value. Women must enjoy the same status, the same recognition and the same consideration as men. They must be offered equal opportunities to fully realize their potential within society. They must settle their lives according to their aspirations, participate in the acquisition of resources and benefit from the resources of society, enjoy equal freedoms and quality of life, and claim equal practical results in all aspects of life. ${ }^{5}$

This Fourth World Conference has had a strong participation of Congolese women. This showed the dynamism and determination of the latter to rebuild a state where women rights are taken into account. For example, they presented a workbook in which they called for the participation of women in decision-making bodies up to a maximum of 30 percent. It should be noted that this World Conference took place at the time of the great challenges of the long transition that had been experienced by the country which had begun in April 1990 to end with the promulgation of the Constitution of the DR.Congo of 18 February 2006.

As of 1996, the Democratic Republic of the Congo has therefore undertaken programs and measures to implement the Beijing Plan of Actions. Thus, it was organized in Kinshasa the capital of the DR.Congo in 1996 a workshop bringing together all the women organizations, with a view to a grouping according to the 12 critical areas considered as the fundamental obstacles to the advancement of women. Among these areas we can cite the participation of women in political institutions.

$\checkmark$ Convention on the Elimination of all forms of Discrimination against Women (CEDAW)

Article 7 of the Convention on the Elimination of All Forms of Discrimination against Women (CEDAW) reaffirms the importance of the presence of women in the political life of their countries, ${ }^{6}$ ensuring to them in equal conditions with men the rights:

${ }^{5}$ http://beijing20.unwomen.org/en.

${ }^{6}$ https://en.wikipedia.org/wiki/Convention_on_the_Elimination_of_All_Forms_of_Discrimination Against_Women. 
- To vote in all elections and in all public referendums and be eligible for all publicly elected bodies;

- To take part in the development of State policy and its execution, to hold public jobs and to exercise all public functions at all levels of governance.

$\checkmark$ United Nations Security Council resolution 1325

In this resolution, the UN Security Council stresses the need to incorporate a gender-specific approach into all peacekeeping and peace building operations and peace-building and also to provide for women participation in key institutions and decision-making bodies on peace-building and peacekeeping. Furthermore, the United Nations Security Council reaffirms ... the important role they play and it recalls that they must participate on an equal footing with men and be fully involved in all efforts towards peacekeeping and security. It highlights the need to increase the role of women in the development of decisions on conflict prevention and resolution. ${ }^{7}$

For example, women have been actively involved in the achievement of all the tasks assigned to the transition, despite their small percentage in the transition institutions, or 10.4 per cent. Nevertheless, as noted by Mabiala-Mantuba: "Their contribution has been felt through the promotion of women rights, female leadership, social and cultural actions, their role in the fight against poverty, their visibility in the economic sector and in the media" (Idem).

$\checkmark$ Maputo Declaration

Whereas article 66 of the African Charter on Human and Peoples' Rights ${ }^{8}$ provides for the adoption of specific protocols or agreements where necessary, to supplement the provisions of the Charter, and that the Conference of Heads of State and Government of the Organization of African Unity, convened at its thirty-first regular session in Addis Ababa, Ethiopia, in June 1995, endorsed, by resolution AHG/RES. 240 (XXXI), the recommendation of the African Commission on Human and Peoples' Rights to develop a protocol on women Rights in Africa (Maputo protocol). ${ }^{9}$

This protocol has as bedrock:

- Article 18 of the African Charter on Human and Peoples' Rights, which calls upon all States to eliminate all forms of discrimination against women and to ensure the protection of woman's rights, as stipulated in the declarations and International conventions.

This overview of international legal instruments has allowed us to reassure ourselves that women rights are recognized and guaranteed by all international human rights instruments. These include the Universal Declaration of Human Rights, the International Covenants on Civil and Political Rights and on economic, social and Cultural Rights the Convention on the Elimination of all forms of Discrimination against Women and its Optional Protocol, resolutions, declarations, recommendations, decisions, conventions and other regional and ${ }^{7}$ http://www.portal.unesco.org.

${ }^{8}$ http://www.achpr.org/files/instruments/achpr/banjul_charter.pdf.

${ }^{9}$ http://www.achpr.org/files/instruments/women-protocol/achpr_instr_proto_women_eng.pdf. 
sub-regional instruments because they belong to the international. All of these instruments are aimed at eliminating all forms of discrimination against women and promoting equality between men and women.

\section{2) At the National level}

\section{$\checkmark$ Constitution}

The issue of gender mainstreaming in the current constitutional framework had been actively debated by civil society during the transitional period 2003-2006. The results of this debate transpire through articles (14 and 15) of the Constitution which focus specifically on women rights and violence against them. ${ }^{10}$ To support this, Muila-Akele, A. S. (2010: p. 189) attests that: “(...) The Constitution of 2006 went beyond the previous fundamental laws. To this end, under the influence of international human rights instruments ratified by the Democratic Republic of the Congo and the claims of women associations, the constituent of 18 February 2006 has taken a number of provisions to improve the plight of women".

However, Article 14 stipulates that: "The public authorities shall ensure the elimination of all Forms of Discrimination against Women and ensure the protection and promotion of their rights. They take in all fields, particularly in the civil, political, economic, social and cultural spheres, all the appropriate measures to ensure the full fulfillment and fully participation of women in the development of the nation.

They are taking steps to combat any form of violence against women in public life and in private life. Women have the right to equitable representation in national, provincial and local institutions.

The State guarantees the implementation of gender parity in the so-called institutions.

The law lays down the modalities for the application of these rights."

From the foregoing, it appears that article 14 of the Constitution clearly establishes the responsibility of the public authorities in eliminating any form of discrimination against women and underscores their quality as guarantor of their rights. This article also states that the Government must take measures to ensure the total participation of women in the development of the country and the fight against violence against women in the public and private spheres.

This article formulates the principle of parity in the public sector and the responsibility of the State in putting it into practice through appropriate laws. It is on the basis of this article that the Parity Law was promulgated on 1st August 2015.

$\checkmark$ National Gender Policy

The gender policy document is intended to be a unifying framework for guiding and coordinating the various interventions aimed at promoting equity and gender equality in the DR.Congo ${ }^{11}$. It includes five chapters to:

- The presentation of the international and national context of the develop${ }^{10} \mathrm{http}: / /$ www.leganet.cd/JO.htm\#2006.

${ }^{11}$ https://www.google.com.hk/search?newwindow=1\&safe=strict\&q=MINIGEFAE,+2009. 
ment of the document;

- Situation analysis of gender disparities in the Democratic Republic of the Congo;

- Challenges to be faced by this national gender policy;

- The policy framework for programmatic guidance and finally;

- The institutional framework for implementation.

Based on its strategic framework, National Gender Policy (PNG) focuses on four key areas:

- The equitable promotion of the situation and the social position of women as well as men in the family and in the community;

- The equitable promotion of the potential and position of women as well as men in the household economy and in the economy of the market;

- The promotion of the equitable exercise of the rights and duties of women and men and the strengthening of women access and position at the level of the decision-making sphere;

- Improving the impact of gender equity interventions and equal access for men and women.

It is these different axes that are taking our attention as part of this reflection.

\section{$\checkmark$ Parity Act}

The elaboration of the law laying down detailed rules for the application of women rights and parity is an application of article 14 of the Constitution of 18 February 2006. It reinforces the commitment of the Congolese State to build a more just society where the behavior, aspirations and different needs of man and woman are taken into account. Thus, the purpose of this Act is to promote gender equity and equal rights, opportunities and genders throughout national life, including the equitable participation of women and men in the management of State affairs (Explanatory memorandum to Law n ${ }^{\circ} 15 / 013$ of 1 August 2015).

As provided in its Articles1-2 entitled General provisions and in accordance with article 14 of the Constitution, these rights concern:

- The elimination of any form of discrimination against women and the protection and promotion of their rights;

- The total flourishing and full participation of women in the development of the Nation;

- Protection against violence against women in public and private life;

- Equitable representation within national, provincial and local institutions;

- Parity between men and women.

The provisions of this Act apply to all areas of national life, including political, administrative, economic, social, cultural, judicial and security. And, in article 6, it is stated that the State adopts specific strategies to ensure equal opportunities for participation between women and men in all electoral processes, including the administration of elections and the voting. It ensures that men are included in all activities related to gender and community mobilization. After presenting the legal and political framework for the promotion of women in this study, we 
analyzed the elimination of all forms of discrimination against women and the promotion of equality between men and women. Moreover, it seems imperative to us to present parity in the national and legislative executive in the Democratic Republic of the Congo which is our interest in this article. Monitoring of the aspects relating to the low representation of women within the national executive in DR.Congo will be the basic subject of this work.

\subsection{Status of Gender Parity in the Institutions of the DR.Congo}

Since the succession of the various Governments of the Democratic Republic of the Congo, the national executive branch has given only a very limited place to women in national institutions. Indeed, the percentage of women in the first $\mathrm{Na}$ tional Government resulting from the 2006 general elections was $7.8 \%$ of women ministers, whereas in the government that ended we see an increase. At the level of parliament, 500 national MPs made up of men and women, the number of women was under-represented by only 44 women, or $8.8 \%$ of women, while the upper house of the senate had only $5 \%$ of women underrepresented out of the 120 senators made up of men and women, which is obviously a very low score until 2012, the Congolese woman is not sufficiently represented in the positions of responsibility.

The extent of inequality to its detriment is immense. The parity process in the Democratic Republic of the Congo is therefore non-evolving. As an ideal to be achieved, it must drink a dynamism that allows it to gain momentum that could cause upheaval in the Congolese political field. The tables below give some indications on the statistics of women occupying positions of responsibility in national institutions between 2006 and 2018 (Tables 1-3).

Table 1. Statistics for women in senior positions in national institutions 2007-2010.

\begin{tabular}{ccccccc}
\hline Category & $\begin{array}{c}\text { Year } \\
\text { 2006-2010 }\end{array}$ & $\begin{array}{c}\text { Total } \\
\text { Staff }\end{array}$ & Woman & Percentage & Man & Percentage \\
\hline Government & - & 43 & 7 & 16 & 36 & 83.7 \\
Parliament & - & 500 & 44 & 8.8 & 456 & 91.2 \\
Senate & - & 120 & 6 & 5 & 114 & 95 \\
Total & - & 879 & 69 & 7.8 & 810 & 92.15 \\
\hline
\end{tabular}

Source: Conseil national de la femme. Guide biographique des femmes cadres leaders. Ministre des affaires socials, Kinshasa, 2006.

As an indication, the percentage of women in the first National Government resulting from the general elections from 2006 to 2010 was $7.8 \%$, which is obviously a very low score. The change in government from 2010 to 2012 did not significantly improve the situation. Indeed, the number of women ministers and deputy ministers rose from 7 to 8 for the Government in mid 2015 (17.1\%). Thus, Table 2 below shows that women who are under-represented in government in the category of women ministers and deputy ministers. Indeed, out of 47 members of the government that makes up the total workforce (Minister of 
State, Ministers and Deputy Ministers and Ministers pre prime ministers/men and women), have 8 women ministers in 2012 until mid 2015, or $17.1 \%$ all positions combined are eligible for women. On the other hand, Parliament leads (500 women) of which 47 women, or $9.4 \%$ followed by the Senate (120) of which 9 women, or $7.5 \%$. The woman is still under-represented in both Houses of Parliament.

Table 2. Statistics for women in senior positions in national institutions 2007-2010.

\begin{tabular}{ccccccc}
\hline Category & $\begin{array}{c}\text { Year } \\
\text { 2006-2010 }\end{array}$ & $\begin{array}{c}\text { Total } \\
\text { Staff }\end{array}$ & Woman & Percentage & Man & Percentage \\
\hline Government & - & 47 & 8 & 17.1 & 39 & 82.9 \\
Parliament & - & 500 & 47 & 9.4 & 453 & 90.6 \\
Senate & - & 120 & 9 & 7.5 & 111 & 92.5 \\
Total & - & 667 & 64 & 34 & 603 & 266 \\
\hline
\end{tabular}

Source: Archives des l'Assemblée. Kinshasa, 2010.

Table 3. Statistics for women in senior positions in national institutions 2006-2018.

\begin{tabular}{ccccccc}
\hline Category & $\begin{array}{c}\text { Year } \\
\text { 2006-2010 }\end{array}$ & $\begin{array}{c}\text { Total } \\
\text { Staff }\end{array}$ & Woman & Percentage & Man & Percentage \\
\hline Government & - & 67 & 13 & 19.4 & 54 & 80.6 \\
Parliament & - & 500 & 64 & 12.8 & 436 & 87.2 \\
Senate & - & 108 & 23 & 21.2 & 85 & 78.7 \\
Total & - & 675 & 100 & 54 & 619 & 274.9 \\
\hline
\end{tabular}

Source: Archives des l'Assemblée. Kinshasa, 2018.

The above statistics provide gender parity in the national and legislative executive in the Democratic Republic of the Congo from February 2006 to March 2018. It is important to note that Table 3 above tells us that at present the national executive branch only gives an evolutionary place to Congolese women in the government. Indeed, the percentage of women in the current National Government does not exceed a significant number of 13 women, or $19.4 \%$ in the ministerial post which is obviously a very advanced score. The 2018 parliamentary elections also allowed it to have a small number of women to exercise legislative power, since they represent only 64 women MPs or $12.8 \%$, while at the level of the National Assembly followed by 23 women senators, $21.2 \%$ in the Senate. Whatever progress is made in this implementation, the representation of women is still insignificant within the institutions of the republic.

If one admits with Le Doaré, H. (2007: p. 150) that "parity as a principle requires that women and men be in a relationship of absolute equality within the Government", then the advances and setbacks that we see simultaneously in the careful scrutiny of the data contained in these graphs, give rise to concerns. The $30 \%$ (which goes against the principle of equality) that women have claimed at the Beijing conference, in Sun City and/or in Nairobi, are not even reached by 
half.

In another register, this hierarchical and gendered representation of the staff of the different governments which succeeded each other from 2007 to 2018, allows us to affirm the following:

- Applied to the Congolese political field through a process of legitimizing the naturalistic ideology, the sexual division of Labour assigns to men very high value functions (Kergoat, 2007: p. 36). Although on a horizontal level women and men are members of the government, vertically, it is exclusively men who held strategic positions 2007 to 2017, the duties of Prime minister, Deputy Prime Minister and minister of state;

- The differentiated valence, conveyed by language and representations, justifies the prioritization of groups leading to an unequal distribution of social roles (Parini, 2006: p. 36): Ministries occupied by women in government have less prestige (Culture and Art, gender, family and children, human rights, etc.) compared to those occupied by men (domestic, Budget, Finance, National Defense, Foreign affairs, etc.).

All in all, for a decade, the path taken by parity has not been linear. It appears rather as a saw-tooth as we have seen. And this discrimination is revealed by the absence of women in political. That is why it is important to continue the fight on practices, words and myths to change deeply the minds.

Indeed, the gendered presentation of government mounts allows us to issue an arresting statement: Despite the ratification of the international and regional instruments for the protection of the rights of women listed in the previous point, there is inertia in practice. That is, there is a discrepancy between the willingness of the public authorities to adhere to these instruments and the effectiveness of their application respects for the Constitution of the Democratic Republic of the Congo in its entirety through the participation of women in all institutions and has all levels of decentralized entities. This is the way to create and reinforce a policy of recognition that promotes social status. That is to say, the status of women as a fully fledged partner in the political interaction.

Women, we all know, "have been subtracted from the political field because of their gender", to use the expression from Le Doaré, H. (2007: p. 150). In this sense, parity as a principle that contradicts the logic of this field requires not only the commitment of the public authorities and the whole community, but above all and of more, a militant commitment of women themselves. Because, the reconfiguration of power relations in the political field, "would render, if not obsolete at least illegitimate, persistent discriminations and lead to other mutations, by their only symbolic force ..." (Gaspard et al., 1992: p. 184).

It seems appropriate to indicate that this is such an important point that it has allowed us to respond to our thinking. Secondly, we think with the legislative elections have allowed only a small number of women to exercise legislative power, since they represent fewer Members of Parliament and Senators. Besides, the presence of women in provincial institutions is also at a very low rate this is said due to external pressures that these laws are often voting and this ash their 
effectiveness.

To this end, the Democratic Republic of the Congo is struggling to vote laws can be to trust outside because they enforce laws following external pressures.

Sometimes the Congolese State makes commitments at the international level to avoid certain pressures, it also votes some law in accordance with international commitments, then the State actors of the Interior of the country are not ready to break with personal convictions, personal wishes without being guided by laws that have been voting in their own country. But also, there is pressure because the state does not reserve any arrest or sanction against such behaviors deviant by our respect for text in DR.Congo. In the lines that will follow, we will try to analyze some factors that help to fuel inertia in the Congolese political field.

These include institutional, socio-cultural, education, socialization and politics factors.

\subsection{The Low Presentation of Women in the National Executive in the DR.Congo}

It is no longer to show that the mould of socialization produces different effects depending on whether it is about man or woman. In one, it reinforces domination, while in the other it sharpens the submission (Bourdieu, 1998: p. 41).

The Congolese society therefore has enormous difficulties in deconstructing the inequalities between women and men in all areas of society and especially in politics. This is because on the one hand, factors related to the context of Congolese socio-cultural gravity and on the other hand those related to the perception of the woman of herself.

Institutional factors

The feminist conceptualizations of the state attest that the latter, through its institutions, crystallize the unequal rules and/or practices that grant differentiated access to social property and restrict the freedom of one or the other social group. These institutions are in the form of laws. At this level, it is necessary to denounce "(...) the way in which the state institutionalizes the relations of power (...) through the legal and politico-administrative apparatus (...) through a distribution of social benefits to men" (Parini, 2006: p. 87).

Indeed, the analysis of the Congolese normative framework refers to the discriminatory provisions against women in national laws among other things in the Family Code, the Labour Code and the Criminal Code. This contradicts the international instruments to which we alluded to the first point. Rightly, Thérèse Nkaku and Mrs. Muangila say: All these legal frameworks have no impact on the lives of Congolese women (...) Despite the key reforms contained in the new Constitution of the Democratic Republic of the Congo and the various recommendations made by the CEDEF committee, Congo legislation remains contradictory and discriminatory against women at different levels (...) As well as what is mentioned by the authors quoted, it should be emphasized here that in the 
National Executive, these are nominating positions that intervene. Where women remain discriminated by the electoral law as well as by the political and judicial systems. Discrimination is particularly evident at the level of work, education, political and socio-economic rights (Interview granted by Nicol Kudiangela at the Radio Okapi). ${ }^{12}$

In the end, we do not deny that the Congolese legal Arsenal has seen a significant improvement in the advancement of women. But it is illusory to think that "laws taken by the state can solve all the problems posed in society and that it is sufficient for the latter to develop" good laws "to make it Happen".

When we consider, for example, electoral Law $N^{\circ} 11 / 003$ of June 25, 2011 on the holding of the elections in DR.Congo, we find that the measures, which are supposed to implement gender parity, are not such as to deconstruct the character andocentric of the Congolese political field (Constitution de la République Démocration du Congo, 2006). Having said that, under article 12 of the said Law, the following is stipulated: "A list shall mean a document drawn up by political parties, political groups or self-employed persons with several names of candidates. Each list is established taking into account, whether it was gender representation and the promotion of the person living with handicap. Thus, in a constituency of more than two seats, at least one third of the candidates presented on a list must be of the other sex". Similarly, article 13 of the same law states in its last paragraph that: “(..) however, the non-achievement of gender parity $(. .$.$) is not a ground for inadmissibility of a list".$

The examination of these two articles, although quoted at length, allows us to issue the allegation that the electoral law of 2011 had not foresee any binding measures, which could lead political parties to respect parity on the lists Electoral.

The state has thus played a large role in the articulation between practices and representation of the difference. Through the patriarchate-the founding mechanism of male domination-it has played an essential role in the construction and perpetuation of gender inequalities by putting in place laws that restrict women rights in the public sphere as we have just demonstrated.

Socio-cultural factors

The cultural perceptions of the society in which women live have an impact on the formulation of their needs and therefore their rights. The bad news interpretation of religious principles. These cultural perceptions are decisive both of men's attitudes towards women and of their practices in the political field. Because "gender is a cultural fact that is created and changed in, by and for culture". 13

To explain the low representation of women in the national executive, we have identified the following socio-cultural factors: education received from women, socialization, both primary and secondary, social prejudices and stereo-

${ }^{12}$ https://www.radiookapi.net/.

${ }^{13}$ https://www.peacewomen.org/. 
types about women, the feminization of poverty and the low rate of female education.

1) Women's education

The role played by education is crucial, as an effective means of establishing a culture of equality, justice, tolerance, peace (Dewey, 2011). For this purpose, the right to education is a fundamental right to train a human being by developing his desire to know, to know throughout his growth, by placing him in a balanced social environment.

Indeed, the efficient contribution of women to the education process, both at the family and the national level, remains dependent on the education sector. It is noted that a high rate of illiteracy among Congolese women, 75\% of whom cannot read, write or calculate. Most literacy programs are often limited to basic French and numeracy courses, including the Alliance-Franco-Congolese program. Civic education, which could enable women to know their rights and duties in order to actively participate in and assume responsibilities in the national development process, is not on the agenda. What doesn't help to change much about her state as a woman ignorant of her rights?

On the other hand, the second Demographic and Health Survey (EDS-RDC II, 2013-2014) found that 36\% of Congolese women are illiterate, while in men this proportion is $11 \%$. The proportion of illiterate women is therefore threefold higher than that of men.

In the same vein, the National Survey of Children and adolescents outside the school (EDS-RDC II, 2013-2014), highlighted the fact that among children outside the school, girls accounted for more than half, or $52.7 \%$. It is also in the latter that the magnitude of this phenomenon is the strongest: $31.7 \%$ among girls versus $26.5 \%$ among boys.

These disparities do not put women and men under the same conditions of access to the political space.

- Ignorance of their rights due to lack of training and information;

- The school loss of girls which is a logical consequence of the sexist division of work that assigns to women the reproductive activities, etc.

However, these findings should not overshadow the efforts made by the Democratic Republic of the Congo, as it is one of the groups of countries that have made the largest increase in school enrolment in recent years. On the one hand, we also note that many girls, have completed post-secondary education and completed their diplomas, bachelor's degrees, graduate degrees and doctorates, although they are still very few. On the other hand, their participation is very insignificant given their very small number compared to their male colleagues. In addition, despite having the same level of qualifications or competence as their male colleagues, women have difficulty accessing senior positions of responsibility.

2) Women primary and secondary socialization

In the Democratic Republic of the Congo, women demand the equitable distribution of social responsibilities and above all their participation in deci- 
sion-making in institutions, international organizations and businesses. This, in reference to the Constitution of the Republic which states in Article 14 that "the public authorities ensure the elimination of all forms of discrimination against women and protect and promote his rights; women have the right to equitable representation in national, provincial and local institutions. The State guarantees the implementation of gender parity in these institutions".

Despite these legal provisions, certain cultural prejudices continue to obstruct women employment, deeply incompatible with her status as a wife, mother and housewife with the demands of the professional world. This contributes, beyond the lack of available jobs, to the reduction of the number of women workers in professional organizations

3) Social prejudices and stereotypes about women

Whether in terms of division of roles, matrimonial practices, management and access to resources, social norms generally assign women a lower status than men, although some nuances sometimes prove to be Company to another. Supporting this idea with Parini, L. (2006: p. 35) attests that: "Gender regimes may vary in time and space, but historians and anthropologists have shown that in most of the studied cultures the female pole is devalued and therefore subordinate to the male pole".

Generally, a stereotype is defined as: "A simplistic image, a click he that is reported to a class of people, an institution or a culture" Hamza, N. (2006: p. 40). This notion is often used negatively to denounce a received and false idea that hinders the true knowledge. The Constitution of stereotypes only reaches the recognition of objects on the basis of images or schemes pre built.

The persistence of stereotypes in the Democratic Republic of the Congo, especially those referring to the status of women, is a testament to the difficulty that still exists today in admitting a non-stereotypical idea of the human being, whose freedom and singular identity do not allow themselves to be locked into categories all made.

There is a series of ideas received and images preconceived around gender parity in the public sphere, which condition the vision that Congolese society is making of this concept. Very often folk songs are true vectors of the objectification of women and their exclusion from the political space.

Without claiming a complete enumeration, here are some of these ideas contained in the popular songs:

- "The intelligence of the woman can never in any way surpass that of the man and the intelligence of the woman is like a small child" because it is comparable to that of a small child;

- "Woman cannot build a country";

- "Women who engage in politics are prostitutes, etc.".

The list of stereotypes promoting male domination within the policy outlined above is not exhaustive. Nevertheless, it allows us to grasp how the Congolese normative imaginary enriches social practices that keep women outside the po- 
litical field.

4) The feminization of poverty

Over the past two decades, the Democratic Republic of the Congo has been the scene of massive and dramatic displacement of populations due to natural disasters and especially to the multiple armed conflicts that are shaking it. This leads to enormous losses, both human and economic, exacerbating poverty. In the face of this reality, several laws relating to the legal care and psycho-social and medical support of women victims of violence have been enacted, including Law 06/018 of July 20, 2006 amending and supplementing decree 06 August 1959 under the Congolese Penal Procedure Code.

During these moments of war, women have often been the victims of rape and various degrading inhuman treatment perpetrated by death, members of armed groups, resulting in death, unwanted pregnancies, sexually transmitted diseases (MST, AIDS). Women are also subjected to harassment and discrimination in professional and school settings. This context of violence and poverty has reduced many girls' and women access to education and employment, and does not allow them to make a meaningful contribution to their communities' development efforts. Yet gender equality was instituted by the constitution of 18 February 2006 (Article 14), which excludes any form of discrimination, particularly related to gender, whether it is access to education or employment.

Some people are unaware that women have access to more limited natural, material and financial resources than men. Poverty is a reality that strikes the majority of Congolese women, who thus see their freedom of action reduced.

Moreover, the statistics published by the Ministry of Planning (2003 and 2010) show that, in the Democratic Republic of the Congo, $44 \%$ of women have no income compared to $22 \%$ of men. Thus, women are doubly poorer than men. As a result, their ability to negotiate in the political game is diminished.

This unequal access to resources has important consequences for the capture of political power by women. This means that the involvement of women in decision-making bodies necessarily and inevitably involves their economic and financial empowerment.

\section{$\checkmark$ Personal factors}

In another register, the lack of solidarity within women movements poses a significant threat to their conquest of the public space. As we have already pointed out earlier, the redefinition of social sex relationships in the Congolese political field requires a militant commitment by women themselves.

Indeed, the conflict of leadership leads to fragmentation of organizations and collectives. This significantly weakens women struggle for parity in public institutions. Women should work together to strengthen existing frameworks. Therefore, their involvement in the public sphere is derisory because it taints subjective considerations.

Now, as David Easton suggests (Grawitz, 2001: p. 439), the women movement should play a role of channeling and filtering. The different groups should be in- 
cluded in the scheme of the recovery of Congolese women claims at the base level, their categorization according to priority claims and finally their pipeline, to the bodies of Power. The latter will be able to take appropriate decisions that could change the asymmetric nature of social relations of sex in the Congolese political field. These factors are the result of precedents:

On the one hand, the political obstacles are not the least, the resignation of the woman from her responsibilities as a wife and mother had tarnished the image of the Congolese woman politician at the time of the Party-State of the Mobutist regime. Nevertheless, the Congolese woman, like the Congolese man, had welcomed the advent of democratization in the hope that this change in the political system would improve the precarious social situation in which she was moving and from which she was the first victim.

However, women have been elevated to the head of businesses and public services under the principles of quota, activism and other personal assets, etc. despite this favoritism, Congolese women have not seen a significant increase in their representation in parliament $(44 / 500$, or $8.8 \%)$ nor to the government where it has never exceeded the threshold of 6 ministers and vice-ministers per mandate, just as in business. And yet the Congolese woman had the right to vote and to stand for election very early compared to other African women and for that matter, since the 1967 referendum in our country the DR.Congo.

It should be noted that, at present, the national executive branch gives only a very limited place to Congolese women. Indeed, the percentage of women in the current National Government has only exceeded a significant number of 13 women, or $20 \%$ in the ministerial post which is obviously a very advanced score. The 2008 parliamentary elections also allowed it to have a small number of women to exercise legislative power, since they represent only 64 of the deputies or $12.8 \%$ at the level of the Assembly and 23 of the senators or $21.2 \%$ in the Senate. Whatever progress is made in this implementation, the representation of women is still insignificant within the institutions of the three powers: executive, legislative and judicial, etc.

In short, socio-cultural barriers mean that women do not closely follow the political life of their country. Power is to men even the laws that come to correct this are little popularized while bills are stifled. All these obstacles of various kinds show that Congolese women do not fully enjoy their rights.

On the other hand, at all times, the woman divides her time between her home and her activities for the survival of the household "small business, market gardening, etc.”. In an economic crisis, women survival activities are supported and, in some cases, compensated for the contribution of the unemployed man.

In the majority of households in the DR.Congo, women have become the first economic operator, as they ensure the survival of the whole family through their activities. This state of affairs means that she has no other concerns than to survive on a daily basis, to the detriment of her own balance. Indeed, the woman who is already out of her home most of the day still has to take care of her home 
when she returns. Husband and children are waiting for him, as well as a lot of housework. It must tackle all its tasks in the most efficient way possible. Her love for her home comes before herself, to the point that at the end of her day she cannot give herself a moment for her training.

It is therefore difficult for a woman who lives in such conditions to flourish. It is essential to empower women to participate fully in economic life in all sectors and at all levels of economic activity. This meets the principles of women empowerment. Having analyzed these different points which do not allow women to emerge because of the social and cultural barriers, women are deprived from participation in the political life of their country. Given that the bills are being suppressed, this proves that the Congolese women do not fully enjoy their rights. In the following point, we will present the point relating to the conclusion of our study.

\section{Conclusion}

The quick overview on "parity in political institutions in the DR.Congo for the emergence of good governance" tells us the articulation between gender and feminisms; both seem to go without saying and I realize however that the subject does indeed deserve a clarification and that the link between the two is not necessarily obvious for everyone. There was a question of proving, in this study, the low representation of women within the Congolese National Executive. This reflection finds its first usefulness in creating a feminist policy of recognition that promotes social status i.e. the status of women as a full-fledged partner in social interaction, and especially political.

Indeed, as already mentioned above, the political field is a space where women are excluded through a process of legitimizing the naturalistic ideology. It is characterized by standards such as competitiveness, stamina, fighting spirit, cunning, etc. These are socially constructed values as masculine. When the Congolese woman embarks on the quest for political space, she must soak up all the logic behind it and develop strategies that will allow her to deconstruct them. Gender equality is not achieved in the attack of one gender in relation to the other but by a complete reconstruction, moving away from them.

In short, the struggle to which it is imperative to confront is manifested on a daily basis, in the form of unequal relations between men and women.

Today, women are often accused of having upset the moral and social codes that harmonize gender relations. Man feels lost in front of these emancipated women. The destruction of this imaginary is a process of long-term but worthwhile to be tempted. It should be recalled that women emancipation does not seek to reverse roles and to dominate men. Indeed, the human being is not meant to submit and to please others.

All in all, we have ambition to believe that the Democratic Republic of the Congo will raise the two major problems for the implementation of the Law on gender parity through the findings made. This is:

$\checkmark$ First: Socio-cultural gravity; 
$\checkmark$ Secondly: The approach to be used to enforce this law.

Let's talk about socio-cultural gravity, because the Cultural Revolution touches on a change in behavior and mentality in a well-defined society and these changes must be accompanied by politics, the economy and it takes time for the achievement. This is how the approach approached did not take into account its burdensome evoke so that the measures of application have the whole level observed cannot be known. On the other hand, the laws that have been put in place must support Congolese women to achieve the development goals, but we note that this law is dragging on to be implemented as stipulated by the Constitution of the Democratic Republic of Congo.

To this end, decision-makers, at different levels, must take stock of the problem and set in motion the effective mechanisms for solving. For example, they will be able to guarantee the schooling of the little girl and the young woman, strictly applying the legal provisions relating to free education currently advocated by the Congolese head of state. Similarly, at the political party level to encourage women access to the head of all different layers especially those considered typically male. Therefore, they should promote equity in women access to leadership positions in all spheres and at all levels that meet their competency profile. It is with this in mind that Congolese women can participate effectively in the development of their country. It's time to awaken the conscience of the Congolese woman.

\section{Acknowledgements}

We acknowledge Pr. Xiaojun Xu, Dean, college of sociology for his constructive feedback on improving earlier drafts of this paper.

\section{Conflicts of Interest}

The author declares no conflicts of interest regarding the publication of this paper.

\section{References}

Akirav, O., \& Ben-Horin, Y. (2016). The Four Anchors Model-Women Political Participant. World Political Science, 12, 241-259. https://doi.org/10.1515/wps-2016-0007

Bereni, L. et al. (2008). Introduction aux Gender Studies. Manuel des études sur le genre. Bruxelles: De Boeck.

Bourdieu, P. (1998). La domination masculine. Paris: Seuil.

Commaille, J. (1997). Les nouveaux enjeux de la question sociale. Paris: Hachette.

Dewey, J. (2011). Démocratie et Education, expérience et Education. Paris: Armand Colin.

Gaspard, F. et al. (1992). Au pouvoir citoyen-nes. Liberté, égalité, parité. Paris: Seuil.

Grawitz, M. (2001). Méthodes de recherche en sciences sociales. Paris: Dalloz.

Hamza, N. (2006). Les violences basées sur le genre. Manuel de formation à lintention 
des écoutantes des Centres d Ecoute de Femmes Victimes de Violence. Maroc, décembre.

JORD. Congo, Constitution de la République Démocration du Congo (2006). Telle que modifiée par la loi no11/002 du 20 janvier 2011 portant re'vision de certaines articles de la Constitution de la Re'publique De'mocratique du Congo du 18 fevrier 2006. Kinshasa, 52ème année, numéro spécial, 5 février 2011. Loin 11/003 du 25 juin 2011 portant organisations des élections en République Démocratique du Congo.

Kassa, S. (2015). Challenges and Opportunities of Women Political Participation in Ethiopia. Journal of Global Economics, 3, 162. https://doi.org/10.4172/2375-4389.1000162

Kergoat, D. (2007). Division sexuelle du travail et rapports sociaux de sexe. In H. Hirata et al. (Eds.), Dictionnaire critique du féminisme (pp. 35-44). Paris: PUF.

Le Doaré, H. (2007). Parité. In H. Hirata et al. (Eds.), Dictionnaire critique du féminisme (pp. 149-154). Paris: PUF.

Loi n ${ }^{\circ} 11 / 003$ du 25 juin 2011 portant organisation des élections en République Démocratique du Congo.

Ministèrede L'enseignement Primaire, Secondaireet Professionnel, Ministèredu Plan (2014). Deuxième Enquête Démographique et de Santé EDS-RDC II 2013-2014. Rock Ville.

Muila-Akele, S. A. (2010). Représentations sociales et rôle de la femme. Perspectives pour la R.D Congo. Congo-Afrique, 443, 181-200.

Parini, L. (2006). Le système de genre. Introduction aux concepts et théories. Zürich: Ed. Seismo, Sciences Sociales et problèmes de société.

Rameez, A. (2018). Political Participation of Women in Local Governance: A Case Study of Selected Local Governance Bodies in Eastern Sri Lanka. Journal of African and Asian Studies, 53, 1043-1061. https://doi.org/10.1177/0021909618762559

RDC (2007). République Démocratique du Congo, Ministèredu Genre, de la Résolution 1325 du Conseil de sécurité des Nations Unies.

Schwartzenberg, R. G. (1998). Sociologie Politique. Paris: Ed Montchestien. Exposé des motifs Loi ${ }^{\circ} 15 / 013$ du $1^{\text {er }}$ août 2015. 


\section{Web Sites}

BURAKOVA-LORGNIER, M., Construction du genre: paradigme et méthodologie de recherche, consulté sur http//www.genreenaction.net/www.cean.sciencepobordeaux Dr Christina Scharff, Why so many young women don't call themselves feminist, King's College London, https://www.bbc.com/news/uk-politics-Accessed on February 12

MABIALA MANTUBA, P., Les femmes et la reconstruction post-conflit en $R D C$, consulté le 10 février 2019 à 17h sur http://www.portal.unesco.org https://cafaitgenre.org/2014/02/25/genre-et-feminisme-pourquoi-vont-ils-de-pai $\underline{\mathrm{r} l}$ http://beijing20.unwomen.org/en https://en.wikipedia.org/wiki/Convention_on_the_Elimination_of_All_Forms_o f_Discrimination_Against_Women http://www.achpr.org/files/instruments/achpr/banjul_charter.pdf http://www.achpr.org/files/instruments/women-protocol/achpr_instr_proto_wo men_eng.pdf

http://www.leganet.cd/JO.htm\#2006

https://www.google.com.hk/search?newwindow=1\&safe=strict\&q=MINIGEFAE $\underline{,+2009}$

http://www.peacewomen.org

https://www.radiookapi.net/ https://www.idea.int/sites/default/files/publications/political-parties-in-africa-th rough-a-gender-lens.pdf http://extwprlegs1.fao.org/docs/pdf/cng154963.pdf 